\title{
Adherence: a review of education, research, practice and policy in Switzerland
}

Marie P. SCHNEIDER, Isabelle KRUMMENACHER, Hugo FIGUEIREDO, Julien MARQUIS, Oliver BUGNON.

\begin{abstract}
Nonadherence to medication treatment regimens is a major preventable risk behavior in both acute and chronic diseases. Community pharmacists are facilitators in community care for promoting medication adherence and they should implement interdisciplinary medication adherence programs. To do so, pharmacists should be educated in medication adherence, and new pharmaceutical care policies should be implemented. The healthcare system should evolve to better meet the specific needs of patients.

Aims: this article describes what has been undertaken in the last decade in medication adherence in terms of education, research, practice and policy in Switzerland.

Methods: Medline was searched, with the search limited to Switzerland. The three Swiss pharmacy schools were also contacted to collect information about the medication adherence content of both their courses and research programs. National policies related to medication adherence were also reviewed for relevant content.

Results: Education: two pharmacy schools offer courses devoted specifically to medication adherence. The number of hours dedicated to the topic varies between 4 to13. Research: a total of 16 studies met the inclusion criteria. Chronic patients were the focus of 9 studies. Medication adherence was the primary outcome of all studies; 10 studies also measured clinical outcomes. Nine studies evaluated the prevalence of medication
\end{abstract}

\footnotetext{
"Marie P. SCHNEIDER. RPh, PhD. Researcher and lecturer in Pharmacy Practice. Community Pharmacy, Dpt of ambulatory care and community medicine, University Hospital, Lausanne (Switzerland).

Isabelle KRUMMENACHER. RPh, PhD student. Pharmacy Practice Unit. Pharmacy School, Universities of Geneva and Lausanne (Switzerland).

Hugo FIGUEIREDO. RPh, PhD student. Pharmacy

Practice Unit. Pharmacy School, Universities of Geneva and Lausanne (Switzerland).

Julien MARQUIS. RPh, PhD student. Pharmacy Practice Unit. Pharmacy School, Universities of Geneva and Lausanne (Switzerland).

Oliver BUGNON. RPh, PhD. Head of Pharmacy Practice Unit. Pharmacy School, Universities of Geneva and Lausanne (Switzerland).
}

Series editors:

Marie P. SCHNEIDER. PhD. Researcher and lecturer in Pharmacy Practice. Community Pharmacy, Dpt of ambulatory care and community medicine, University Hospital, Lausanne (Switzerland).

Parisa ASLANI. PhD. Senior Lecturer in Pharmacy

Practice. Faculty of Pharmacy, University of Sydney (Australia). nonadherence; three studies evaluated the feasibility of new technologies for monitoring adherence; three studies evaluated medication adherence enhancing programs. Policies: three cognitive pharmaceutical services are reimbursed by healthcare insurers, which are directly related to medication adherence.

Conclusions: Pharmacists in Switzerland have been actively involved in medication adherence research since the mid ' 90 s. Specific medication adherence courses have entered the curriculum of pharmacy schools, and policies in Switzerland are slowly beginning to meet needs of chronic patients by the introduction of pharmaceutical cognitive services and reimbursement fees.

Keywords: Medication Adherence. Pharmacists. Switzerland.

\section{CUMPLIMIENTO: REVISIÓN DE LA EDUCACIÓN, INVESTIGACIÓN, PRÁCTICA Y POLÍTICA EN SUIZA}

\section{RESUMEN}

El incumplimiento de los tratamientos farmacológicos es un comportamiento de riesgo serio prevenible tanto en enfermedades agudas como crónicas. Los farmacéuticos comunitarios son son facilitadores en atención primaria para promover la adhesión a la medicación y deberían implantar programas interdisciplinarios de cumplimiento medicamentoso. Para ello, los farmacéuticos deben ser educados en adhesión a la medicación y deben implantarse nuevas políticas de atención farmacéutica. El sistema sanitario debería evolucionar para cumplir mejor las necesidades específicas de los pacientes.

Objetivos: este artículo describe lo que se ha realizado en la última década sobre adhesión a medicación en términos de educación,

investigación, práctica y política en Suiza. Métodos: Se buscó en Medline, limitando la búsqueda a Suiza. Se contactó a las tres facultades de Farmacia de Suiza para recoger información tanto sobre sus cursos como sobre sus programas de investigación. También se revisaron las políticas nacionales a la búsqueda de contenidos relevantes. Resultados: Educación: Dos facultades de farmacia ofrecieron cursos específicamente dedicados a adhesión a la medicación. El número de horas dedicado a estos temas varió de 4 a 13 .

Investigación: 16 estudios cumplieron los criterios de inclusión. Los pacientes crónicos fueron el foco de 9 estudios. El cumplimiento de la medicación 
fue el resultado principal de todos los estudios; 10 estudios también midieron resultados clínicos. 9 estudios evaluaron la prevalencia del incumplimiento; 3 estudios evaluaron la viabilidad de las nuevas tecnologías para el seguimiento de la adhesión; 3 estudios evaluaron programas de aumento de cumplimiento. Políticas: · servicios cognitivos farmacéuticos están siendo remunerados por las aseguradoras y están directamente relacionados con el cumplimiento de la medicación. Conclusiones: La farmacia en Suiza se ha involucrado activamente en investigación sobre cumplimiento de la medicación desde mediados de los 90. Cursos específicos de cumplimiento de la medicación han entrado a formar parte del currículo de las facultades de farmacia, y las políticas en Suiza están comenzando lentamente a satisfacer las necesidades de los pacientes crónicos con la introducción de servicios cognitivos farmacéuticos y remuneración.

Palabras clave: Adherencia a la medicación. Farmacéuticos. Suiza.

\section{INTRODUCTION}

Nonadherence to medication treatment regimens ('medication nonadherence') is a major preventable risk behavior in chronic diseases. Missing doses is a natural behavior - every patient misses doses once in a while usually without important clinical consequences - but it may become pernicious if it is frequent enough to impact negatively on therapeutic outcomes. This is exemplified in the treatment of the Human Immunodeficiency Virus (HIV). Since the mid ' 90 , HIV patients have become chronic patients largely due to the new potent combined antiretroviral therapies. However, ongoing medication adherence to the treatments needs to remain high (>90\%) to prevent (1) the emergence of drug resistance strains and (2) treatment failure.

Medication adherence has become the new MeSH term in Medline since January 2009 and replaces the old term, patient compliance. Adherence is an active, intentional and responsible process of care in which the patient works to maintain health in close collaboration with healthcare providers. Medication adherence implies two different behaviors. On the one hand, persistence, which means the duration of dosing before patient's premature interruption of treatment, and, on the other hand, good quality of execution, which describes the daily patterns of patient adherence behavior (e.g. percentage of days with correct dosing, percentage of correct dosing intervals, drug holidays).

It has long been recognized that healthcare systems need to evolve to better meet the specific needs of chronic patients. ${ }^{2}$ Healthcare providers should support their chronic patients by prescribing and delivering pharmacologically-sound treatments adjusted to specific patient needs. To ensure optimal use of treatment, healthcare providers must also explore patient knowledge and understanding of disease and its treatment, beliefs and expectations, motivation, self-efficacy and readiness to treatment, and behavioral skills to ensure optimal integration of treatment into patient life style. Medication adherence is a dynamic behavior, which changes with time according to life circumstances. Therefore, it should be tracked over the long-term.

Chronic patients encounter several healthcare providers along their way, among them, their general practitioner, specialist physicians and their pharmacist. Unfortunately, healthcare providers usually do not collaborate. In fact, care is often sequential and inefficient as potentially useful information is not consistently exchanged or reinforced by all care providers.

A key professional responsibility of community pharmacists is to promote medication adherence. In fact, pharmacists are well positioned to identify and address medication adherence issues with their patients and provide an adherence report for physician review. This would allow physicians to consider adherence results as part of their decision making. Pharmacists are ideal partners and facilitators in community care for promoting medication adherence as it is often less difficult for patients to address nonadherence issues with someone other than the prescribing physician, to whom they may feel bonded.

However, to fulfill this role, pharmacists as well as other healthcare providers must be educated in medication adherence. Specific courses should cover medication adherence theories, relevant communication skills and relevant practice guidelines. An example is the recently published British National Institute for Health and Clinical Excellence (NICE) medication adherence guidelines for professionals and patients. ${ }^{3}$

Meanwhile, patient expectations of pharmacist's role should also evolve. Patients need to be informed of the potential and progressive shift from pharmacists dispensing chronic medications to pharmaceutical care programs, which emphasize the resolution of drug related problems such as medication nonadherence. Medication nonadherence should be addressed specifically with patients very early on in the course of their chronic treatment before nonadherence has become such an issue that patients become reluctant to express concerns and perceived difficulties with prescribed treatments.

This article describes what has been undertaken in Switzerland in terms of the education, research, practice and policy of medication adherence.

\section{METHODS}

\section{Medication adherence education, research and practice}

The three Swiss pharmacy schools - Basel, Geneva, and Zurich - were contacted and were asked to fill in a structured self-completion questionnaire about medication adherence in their 
curricula, their medication adherence related research and the practice of medication adherence specific services in community pharmacy. Two items of the questionnaire focused on pre-graduate and post-graduate education in medication adherence. Respondents were asked to provide detailed information about the way education in medication adherence is structured and when the courses are taught. One item requested information on past and on-going research into medication adherence and for any related references. Three items were devoted to practice in community pharmacy: (1) the way community pharmacists address medication adherence with their chronic patients, (2) whether community pharmacists run specific adherence intervention programs, and (3) whether any interdisciplinary collaboration exists between community pharmacists and other healthcare providers or the pharmaceutical industry for promoting medication adherence.

\section{Research in medication adherence}

The database MEDLINE was searched, with the search limited to Switzerland from 1975 to present. The following key-words were used: patient compliance OR patient adherence OR medication adherence OR pharmaceutical services OR pharmaceutical care. Searches were also conducted based on the names of key Swiss researchers in the areas of medication adherence and pharmaceutical services. The study was included if pharmacists were involved in measuring and/or supporting patients' adherence to chronic medication. All study designs were included. Each retrieved article was then reviewed based on the study design, methods for measuring medication adherence, study outcomes and results.

\section{Policy}

National policies related to medication adherence were also reviewed. The policies are published in an agreement (Convention tarifaire RBPIII) between the Swiss Pharmacist Society and Swiss health insurers ('santé suisse').

\section{RESULTS AND DISCUSSION}

\section{Medication adherence education}

All three Swiss pharmacy schools responded to the questionnaire. They all offer the Bachelor, a 3-year undergraduate degree, and a 2-year Master of Pharmacy degree. During the Bachelor degree, students receive an education in basic medical and pharmaceutical sciences. Depending on the Pharmacy Schools, 2 types of Masters degree are available: 1) a Masters degree in Pharmacy and a Masters degree in industrial pharmaceutical sciences. During the first year Masters degree in Pharmacy, students complete a 6-months advanced pharmaceutical sciences course and a 16-weeks research project. During the second year of the Masters degree in Pharmacy, students complete 20 to 30 weeks internship in community pharmacies and 10 optional weeks in hospital pharmacies, and attend a 12-week on campus course. The Masters degree in Pharmacy is completed by the Federal examination for registered pharmacists. Registered pharmacists can then work in community pharmacies. Advanced Masters or diploma are also available, for example a Master of Advanced Studies in hospital pharmacy, a Master in Pharmaceutical Economics and Policy, a Master in Public Health or a diploma in community health. ${ }^{4}$

The curriculum regarding medication adherence varies widely from one University to the other. Students of all pharmacy schools are taught the topic during the masters training program. Two pharmacy schools offer specific courses devoted to medication adherence and related topics such as patient empowerment, and communication skills and techniques. The number of dedicated hours during the Masters varies between 4 to 13 hours. The third school did not approach the issue specifically but teaches medication adherence when appropriate during other therapeutic courses. Table 1 summarizes the medication adherence courses in the three Swiss pharmacy schools.

In Swiss pharmacy schools, medication adherence is slowly becoming recognized as an important issue that needs to be taught specifically. Nevertheless, the topic probably deserves more attention as patient behavior towards prescribed medications is an important modifier of the effectiveness of community-based chronic treatment. Moreover, the topic is taught at the end of the curriculum, which then coincides with student training in community pharmacies. However, it is important to increase students' awareness earlier on and to give them the opportunity to develop relevant skills more gradually.

Ongoing education in medication adherence for registered pharmacists is regularly provided by Universities, and national or local organizations involved in pharmacists' continuous education, for example, the Swiss Pharmacists Association, pharmaSuisse, and its program pharmActuel ${ }^{5}$ or the Association of community pharmacists CAP $^{6}$ (Centre d'animation des pharmaciens).

Medication adherence education is also provided by other healthcare professionals, for example the University of Geneva offers a diploma in therapeutic education for chronic patients. ${ }^{7}$ All healthcare professionals can attend this 3-year course.

\section{Research in medication adherence}

A total of 16 studies met the inclusion criterion (Tables 2 and 3). The first publication was in 1998. Fourteen studies took place at one site; one was two-centered ${ }^{8}$ and the last one was multi-centered. ${ }^{9}$ All studies have been published in peer-reviewed journals: pharmacology journals, specific medical journals, or technology in health-care journals.

Medication adherence was the primary outcome of all studies; 10 studies also measured clinical outcomes. Nine studies evaluated the prevalence of medication nonadherence as the primary outcome. $^{10-18}$ Three studies evaluated the feasibility of new technologies for measuring adherence (electronic pill containers, for example the Medication Event Monitoring System, MEMS ${ }^{\mathrm{TM}}$ the 
Intelligent Drug Administration System, IDAS II ${ }^{\mathrm{TM}}$ the MEMS $^{T M}$ monitor connected to a personal modem HomeLink ${ }^{\text {TM }}$. $^{19-21}$ Eight studies correlated nonadherence rate to clinical outcomes ${ }^{9,11,12,15,16,18,22,23}$ and, among them, five applied linear regression or multivariate analysis methods. $9,15,16,18,22$ One study evaluated predictors of nonadherence. ${ }^{10}$ Three studies evaluated medication adherence enhancing programs. ${ }^{8,9,23}$

\begin{tabular}{|c|c|c|c|c|}
\hline University & $\begin{array}{l}\text { Degree } \\
\text { (years) }\end{array}$ & Course & Content & Assessment \\
\hline \multirow[t]{3}{*}{ Basel } & $\begin{array}{l}\text { Master } \\
(4)\end{array}$ & $\begin{array}{l}\text { 2-hour course on medication } \\
\text { adherence }\end{array}$ & $\begin{array}{l}\text { Theoretical basis, i.e. definition, measurement, } \\
\text { intervention in the field of adherence in ambulatory } \\
\text { care. }\end{array}$ & Oral exam \\
\hline & \multirow[t]{2}{*}{$\begin{array}{l}\text { Master } \\
\text { (5) }\end{array}$} & $\begin{array}{l}\text { 4-hour workshop on medication } \\
\text { adherence }\end{array}$ & $\begin{array}{l}\text { Workshop on adherence with asthma treatment, } \\
\text { patient education and monitoring. }\end{array}$ & \multirow[t]{2}{*}{ Oral exam } \\
\hline & & $\begin{array}{l}\text { 4-hour workshop on life style } \\
\text { adherence }\end{array}$ & $\begin{array}{l}\text { Workshop on smoking cessation, stages of change, } \\
\text { motivational interview. }\end{array}$ & \\
\hline \multirow[t]{6}{*}{ Geneva } & \multirow[t]{6}{*}{$\begin{array}{l}\text { Master } \\
\text { (5) }\end{array}$} & $\begin{array}{l}\text { 4-hour course on medication } \\
\text { adherence }\end{array}$ & $\begin{array}{l}\text { Definition of medication adherence and persistence, } \\
\text { prevalence, risks linked to nonadherence, } \\
\text { psychological theoretical frameworks, methods for } \\
\text { evaluating/measuring adherence, program and } \\
\text { techniques for promoting and supporting adherence, } \\
\text { case studies. }\end{array}$ & Oral exam \\
\hline & & 1-hour on empathy & $\begin{array}{l}\text { Definition and theory, translation into practice, case } \\
\text { studies }\end{array}$ & \multirow[t]{5}{*}{ Oral exam } \\
\hline & & $\begin{array}{l}\text { 2-hour course on patient } \\
\text { empowerment }\end{array}$ & $\begin{array}{l}\text { Definition, associated concepts (coping, disease } \\
\text { management), translation into practice, case studies. }\end{array}$ & \\
\hline & & 2-hour therapeutic education & $\begin{array}{l}\text { Definition and theory, translation into practice, case } \\
\text { studies }\end{array}$ & \\
\hline & & 2-hour motivational interviewing & $\begin{array}{l}\text { Introduction to motivational interviewing, i.e. its } \\
\text { specific concepts (resistance, self-efficacy, } \\
\text { ambivalence) and clinical skills (empathy, reflective } \\
\text { listening, summaries, etc.); case studies. }\end{array}$ & \\
\hline & & $\begin{array}{l}\text { 2-hour workshop on interviewing } \\
\text { techniques }\end{array}$ & $\begin{array}{l}\text { Discussion of case studies, which students } \\
\text { encountered during training; role-play. }\end{array}$ & \\
\hline Zurich & $\begin{array}{l}\text { Master } \\
\text { (5) }\end{array}$ & No specific course & $\begin{array}{l}\text { Medication adherence is taught during other courses, } \\
\text { especially courses devoted to chronic patient } \\
\text { treatment, all year through. }\end{array}$ & - \\
\hline
\end{tabular}

Chronic patients were the subjects in 9 studies: hypertension ${ }^{9,11,12,20,22}(5)$, lipid-lowering therapy ${ }^{16}$ (1), tuberculosis ${ }^{13}$ (1), HIV $^{8}$ (1), and epilepsy ${ }^{23}$ (1). In thirteen studies, patients were included in the outpatient medical clinics of three University hospitals in Switzerland (Lausanne, Basel and Geneva). Only one study took place in the community (community pharmacists and GPs) ${ }^{9}$ and two included hospitalized patients. ${ }^{10,19}$

Four studies were randomized. ${ }^{9,17,20,23}$ All studies except one ${ }^{10}$ used electronic monitoring to measure medication adherence. Other methods included: pill counts, urine testing, self-reported questionnaire, and structured interviews with patients. A composite score between electronic monitoring, pill count and validated pocket-doses was also defined. ${ }^{8,22}$

Authors of all sixteen studies were pharmacists and physicians. Nurses also participated in one study. ${ }^{8}$ For the most part, physicians recruited study subjects according to clinical inclusion criteria and referred them to pharmacists for the study. This suggests that medication adherence is an issue of interest to various health-care professionals as they share the responsibility with their patients for successful adherence. Most of all, it illustrates that health-care professionals can collaborate with each other as an interdisciplinary team for promoting medication adherence and seamless care. However, we have to explore whether this kind of model can be transferred to community pharmacies and primary care practices. An on-going study in Switzerland is currently addressing this question.

Among the eight studies, which correlated medication adherence to clinical outcomes, five showed a significant association between medication adherence and clinical outcomes: better medication adherence correlated with improved outcomes. $^{12,15,16,18,22}$ In most studies, medication adherence was high, probably because subjects knew they were being monitored (Hawthorne effect). However, subjects had difficulties adhering to complex recommendations (e.g. food restriction, refrigerator storage). ${ }^{17}$ In most studies, attrition rate was low and most patients were satisfied with the protocol. Three studies evaluated adherenceenhancing programs in hypertension, HIV and epilepsy; these early results are promising. Adherence seems to drop faster in control vs. intervention groups ${ }^{8}$ and clinical outcomes appear to be superior in intervention vs. control group. ${ }^{9}$ Larger, randomized trials are needed to confirm these preliminary results.

The latest intervention ${ }^{8}$ combined medication adherence electronic feedback - measured with MEMS ${ }^{\mathrm{TM}}$ caps - with motivational interviewing (MI), an approach developed by Miller and Rollnick ${ }^{24}$ to promote behavioral change. ${ }^{25}$ Motivational interviewing is tailored to patient's needs and readiness to change behavior. ${ }^{26}$ The pharmacist created an individualized, nonjudgmental and 
supportive environment allowing each patient to become an active partner. The intervention relied on Fisher's information-motivation-behavioral skills theoretical framework (IMB), which states that adherence-related information, motivation, and behavioral skills are fundamental determinants of adherence to medication. ${ }^{27,28}$ The intervention was also inspired by social cognitive theory. ${ }^{29,30}$ During the interview, the pharmacist addressed barriers and facilitators (cognitive, emotional, behavioral and social issues) encountered by the patient, which impacted adherence. At the end of each session, the patient brought an adherence report and summary of the intervention to the subsequent physician visit.

In Switzerland, other healthcare professionals such as physicians ${ }^{31}$, nurses ${ }^{32}$, psychologists ${ }^{33}$, statisticians $^{1}$ and health economists ${ }^{34}$ are interested in medication adherence research. Part of this research is interdisciplinary: physicianspharmacists $^{12,16}$, physicians-nurses ${ }^{32}$, physicianspsychologists. ${ }^{33}$

\section{Practice of adherence services and policy}

Community pharmacists are well placed to play a key role in supporting patient medication adherence as they are easily accessible, can meet with patients regularly and share the responsibility with the prescriber and the patient for dispensing medications efficiently and safely. The pharmacist has to answer the patients' individual needs in terms of information, medication handling, and practical integration and social acceptance of treatment into daily routines. Ideally, the pharmacist should address adherence issues empathically with their patients from the first time a medication is dispensed and offer patients the opportunity to talk on an ongoing basis about issues they face with their chronic treatment. This requires establishing and maintaining an appropriate, nonjudgmental environment.

Patient medication history: a tool for detecting nonadherence

Most community pharmacies in Switzerland are equipped with software, which keeps patient medication histories: prescribed and dispensed medicines, pharmacist comments on clinical data, automatic drug interaction checks, and patient dosage cards. This history is a useful indicator of patient medication renewal rate (Table 4). However, the accuracy of such histories can be low especially if the patient does not renew his treatment systematically at the same pharmacy. If nonadherence is detected through the history, an assumption for nonadherence should be validated with the patient and the issue should be addressed empathically.

In Switzerland, many pharmacies are equipped with a little desk on the side, where pharmacists can confidentially interview their patients about adherence issues.

\section{Remunerated cognitive pharmaceutical services}

Six types of cognitive pharmaceutical services are reimbursed by healthcare insurers in Switzerland, the relative costs of which have been defined using a system of rated points. In 2009, the cost of one rated point equals 0.72 Euros (including taxes). ${ }^{35}$ The overall aim of these cognitive services is to specify pharmacist tasks when delivering prescribed medication to patients and increase trust of patients, other healthcare givers and insurers. Among these cognitive pharmaceutical services, two are directly related to medication adherence and both need to be requested by a physician:

1. Weekly medication adherence fixed fee for preparing pill organizers, including electronic monitors for patients with a chronic condition, who take at least three different medicines concomitantly (20 rated points/week).

2. Direct observed therapy (DOT) fixed fee when a patient takes medication in the pharmacy under the pharmacist's supervision (usually 10 rated points/delivery; score differs for delivery of methadone).

A new cognitive pharmaceutical service, called polymedication check, will be implemented during 2009. The pharmacist will be reimbursed for a 20 to 30-minute interview with chronic patients taking at least 4 different and concomitant medications with the possibility of dispensing a pill organizer during the 3 following months. The aim is to tackle complex patients who are at risk of drug-related problems and/or nonadherence, hence the 4 prescribed medications. The interview and the pill-organizer do not need to be requested by the physician for reimbursement. This service can be repeated every 6 months. $^{36}$ This service represents a major improvement as, for the first time, interview time with the patient is reimbursed and the service does not need to be requested by the physician.

\section{CONCLUSIONS}

Specific medication adherence courses have entered the curriculum of two out of the three pharmacy schools in Switzerland. Pharmacists in Switzerland have also been actively involved in medication adherence research since the mid nineteen nineties. Research has primarily focused on nonadherence prevalence. More recently researchers have developed and evaluated programs for supporting medication adherence to long-term treatment. Most of the programs have been developed in specific clinic settings, for example the community pharmacy of an outpatient medical clinic. Present research focuses on the transfer of these programs to other community pharmacies in Switzerland. In fact, the main limitation of the research is that the effectiveness of these programs have not been assessed in large, multi-centered randomized clinical trials. Moreover whether these programs can be implemented successfully in non clinic settings i.e. community pharmacy, is still unknown.

Policies in Switzerland are slowly meeting the needs of chronic patients via implementation of pharmaceutical cognitive services and reimbursement fees. However, much still needs to be done to improve interdisciplinary collaboration in 
order to provide seamless care. The role of the community pharmacists must evolve to meet the adherence challenges of patients with chronic diseases. Patient awareness of this shift in the role of the pharmacist will also have to be promoted and monitored.

\section{ACKNOWLEDGEMENTS}

We acknowledge Dr Isabelle Arnet, pharmacist, and Prof. Kurt Hersberger, School of Pharmacy,
University of Basel, Switzerland, and Prof. Bruno Gander and Mr. Stefan Erni, pharmacist, School of Pharmacy, University of Zurich, Switzerland for completing the questionnaire. We also acknowledge John K. Wagg for his useful comments on the manuscript.

\section{CONFLICT OF INTEREST}

None declared.

\section{References}

1. Glass TR, De Geest S, Hirschel B, Battegay M, Furrer H, Covassini M, Vernazza PL, Bernasconi E, Rickenboch M, Weber R, Bucher HC; Swiss HIV Cohort Study. Self-reported non-adherence to antiretroviral therapy repeatedly assessed by two questions predicts treatment failure in virologically suppressed patients. Antivir Ther 2008;13(1):77-85

2. World Health Organization. Adherence to long-term therapies. Evidence for action. Report of World Health Organization, 2003.

3. NICE recommendation on medication adherence: http://www.nice.org.uk/CG76 (accessed 12-5-2009).

4. Pharmacy School, University of Geneva. http://www.unige.ch/sciences/pharm/f/la_section/edito.php (accessed 28-052009).

5. pharmActuel program: http://www.pharmasuisse.org/fr/pharmazie_fachpublikum/04_publikationen/pharmactuel.php?navanchor=1010013 (accessed 12-5-2009).

6. CAP Association of community pharmacists: http://cours.pharmacap.ch/calendrier/calendrier.asp?lang=fr (accessed 12-52009).

7. Diploma in therapeutic education, University of Geneva: http://www.unige.ch/formcont/difep.html (accessed 12-5-2009).

8. Krummenacher I, Cavassini M, Bugnon O, Spirig R., Schneider MP. Antiretroviral Adherence-Enhancing Management Program in HIV patients: A Feasibility Study in the Swiss HIV Cohort Study (sent for publication).

9. Santschi V, Rodondi N, Bugnon O, Burnier M. Impact of electronic monitoring of drug adherence on blood pressure control in primary care: A cluster 12-month randomised controlled study. Eur J Intern Med 2008;19(6):427-434.

10. Arnet I, Schoenenberger RA, Spiegel R, Haefeli WE. [Conviction as a basis for compliance and strategies for improving compliance]. Schweiz Med Wochenschr. 1999;129(41):1477-1486.

11. Bertholet N, Favrat B, Fallab-Stubi CL, Brunner HR, Burnier M. Why Objective Monitoring of Compliance is Important in the Management of Hypertension. J Clin Hypertens (Greenwich). 2000;2(4):258-262.

12. Burnier M, Schneider MP, Chiolero A, Stubi CL, Brunner HR. Electronic compliance monitoring in resistant hypertension: the basis for rational therapeutic decisions. J Hypertens. 2001;19(2):335-341.

13. Fallab-Stubi CL, Zellweger JP, Sauty A, Uldry C, Iorillo D, Burnier M. Electronic monitoring of adherence to treatment in the preventive chemotherapy of tuberculosis. Int J Tuberc Lung Dis. 1998;2(7):525-530.

14. Landry P, lorillo D, Darioli R, Burnier M, Genton B. Do travelers really take their mefloquine malaria chemoprophylaxis? Estimation of adherence by an electronic pillbox. J Travel Med. 2006;13(1):8-14.

15. Schneider MP, van Melle G, Uldry C, Huynh-Ba M, Fallab Stubi CL, Iorillo D, Burnier M, Zellweger JP.Electronic monitoring of long-term use of the nicotine nasal spray and predictors of success in a smoking cessation program. Nicotine Tob Res 2003;5(5):719-727.

16. Schwed A, Fallab CL, Burnier M, Waeber B, Kappenberger L, Burnand B, Darioli R. Electronic monitoring of compliance to lipid-lowering therapy in clinical practice. J Clin Pharmacol. 1999;39(4):402-409.

17. Stubi CL, Landry PR, Petignat C, Bille J, Genton B, Darioli R et al. Compliance to live oral Ty21a typhoid vaccine, and its effect on viability. J Travel Med. 2000;7(3):133-137.

18. Wermeille J, Cunningham M, Dederding JP, Girard L, Baumann R, Zelger G, Buri P, Metry JM, Sitavanc R, Gallaz L, Merki H, Godin N. Failure of Helicobacter pylori eradication: is poor compliance the main cause? Gastroenterol Clin Biol. 2002;26(3):216-219.

19. Arnet I, Haefeli WE. Overconsumption detected by electronic drug monitoring requires subtle interpretation. Clin Pharmacol Ther. 2000;67(1):44-47.

20. Santschi V, Wuerzner G, Schneider MP, Bugnon O, Burnier M. Clinical evaluation of IDAS II, a new electronic device enabling drug adherence monitoring. Eur J Clin Pharmacol. 2007;63(12):1179-1184.

21. Schneider MP, Burnier M. On-line home monitoring of drug compliance: is it feasible? Eur J Clin Pharmacol. 1998;54(6):489-490

22. Figueiredo H, Tousset E, Burnier M, Vrijens B, Bugnon O, Schneider MP. Medication adherence over time, and association between quality of execution and systolic blood pressure in resistant hypertension (in preparation).

23. Schneider MP, Despland P.A, Buclin Th, Burnier M. Evaluation of online telemonitoring of drug adherence: a pilot randomized, controlled study in patients with epilepsy. J Inform Technol Healthcare. 2003;1(6):419-435.

24. Miller WR, Rollnick S, Conforti K. Motivational Interviewing: Preparing People for Change (2nd edition). The Guilford Press ed. 2002. 
25. Cooperman NA, Arnsten JH. Motivational interviewing for improving adherence to antiretroviral medications. Curr HIV /AIDS Rep. 2005;2(4):159-164.

26. Adamian MS, Golin CE, Shain LS, DeVellis B. Brief motivational interviewing to improve adherence to antiretroviral therapy: development and qualitative pilot assessment of an intervention. AIDS Patient Care STDS. 2004;18(4):229238.

27. Fisher JD, Fisher WA, Amico KR, Harman JJ. An information-motivation-behavioral skills model of adherence to antiretroviral therapy. Health Psychol. 2006; 25(4):462-473.

28. Fisher JD, Amico KR, Fisher WA, Harman JJ. The information-motivation-behavioral skills model of antiretroviral adherence and its applications. Curr HIV/AIDS Rep. 2008;5(4):193-203.

29. Bandura a. Health functioning. In: Bandura a, editor. Self-efficacy, the exercice of control. New York: W.H. Freeman and Co; 1997. 259-318.

30. Munro SA, Lewin SA, Swart T, Volmink J. A review of health behaviour theories: how useful are these for developing interventions to promote long-term medication adherence for TB and HIV/AIDS? BMC Public Health. 2007;7(1):104.

31. Waeber B, Burnier M, Brunner HR. Compliance with antihypertensive therapy. Clin Exp Hypertens. 1999; 21(5-6):973985.

32. Denhaerynck K, Schafer-Keller P, Young J, Steiger J, Bock A, De GS. Examining assumptions regarding valid electronic monitoring of medication therapy: development of a validation framework and its application on a European sample of kidney transplant patients. BMC Med Res Methodol 2008; 8:5.

33. Weber R, Christen L, Christen S, Tschopp S, Znoj H, Schneider C et al. Effect of individual cognitive behaviour intervention on adherence to antiretroviral therapy: prospective randomized trial. Antivir Ther 2004;9(1):85-95.

34. Lamiraud K, Moatti JP. Economic implications of nonadherence to highly active antiretroviral treatment in HIV patients. Expert Opin Pharmacother 2006;7(2):135-143.

35. Guignard E, Bugnon O. Pharmaceutical care in community pharmacies: practice and research in Switzerland. Ann Pharmacother 2006;40(3):512-517.

36. Haas C. RBPIV: Convention envoyée au Conseil fédéral pour approbation. pharmaJournal 2009;(08):20. 


\begin{tabular}{|c|c|c|c|}
\hline Study characteristics & $\begin{array}{l}\text { Measuring methods for } \\
\text { adherence }\end{array}$ & Study outcomes & Results \\
\hline $\begin{array}{l}\text { Schneider et al. }{ }^{21} \text { Design: pilot, run-in period, } \\
\text { longitudinal, one-site. } \\
\text { Aim: to assess if on-line home monitoring of medication } \\
\text { adherence is feasible and acceptable to chronic } \\
\text { patients. } \\
\text { Duration: } 2 \text { months } \\
\text { Number of subjects at inclusion: } 7\end{array}$ & $\begin{array}{lr}\text { Medication } & \text { adherence } \\
\text { electronic } & \text { monitor } \\
\left(\text { MEMS }^{\mathrm{TM}}\right) & \text { connected to a } \\
\text { personal } & \text { modem } \\
(\text { HomeLink } & \text { installed on } \\
\text { the subject's telephone } \\
\text { line. }\end{array}$ & Taking adherence ${ }^{a}$ & $\begin{array}{l}\text { On-line monitoring was well accepted by subjects. } \\
\text { Adherence improved in } 3 \text { patients (from } 76 \% \text { to } 90 \%, 69 \% \\
\text { to } 87 \% \text {, and } 83 \% \text { to } 89 \% \text { ). }\end{array}$ \\
\hline $\begin{array}{l}\text { Fallab-Stubi et al. }{ }^{13} \text { Design: longitudinal, one-site. } \\
\text { Aim: to evaluate the usefulness of an electronic monitor } \\
\text { for measuring adherence to preventive } \\
\text { chemoprophylaxis of tuberculosis with isoniazid. } \\
\text { Duration: } 6 \text { months. } \\
\text { Subjects at inclusion: } 30\end{array}$ & $\begin{array}{l}\text { Continuous electronic } \\
\text { monitoring of medication } \\
\left.\text { adherence (MEMS }{ }^{\mathrm{TM}}\right) \text {, pill } \\
\text { count, urine test for } \\
\text { isoniazid. }\end{array}$ & Taking adherence & $\begin{array}{l}\text { Mean adherence measured by electronic monitors was } \\
91 \%(+/-18.6 \%) \text {. Pill count and urine test tended to } \\
\text { overestimate adherence when compared to electronic data. } \\
\text { Combined intervention of pharmacist and physician } \\
\text { improved medication adherence significantly but transiently } \\
\text { in all } 4 \text { non-adherent patients. }\end{array}$ \\
\hline $\begin{array}{l}\text { Schwed et al. }{ }^{16} \text { Design: open, longitudinal, one-site. } \\
\text { Aim: to monitor adherence to fluvastatin } 40 \mathrm{mg} \text { using an } \\
\text { electronic device vs. pill count. } \\
\text { Duration: } 6 \text { months } \\
\text { Sujects at inclusion: } 30\end{array}$ & $\begin{array}{l}\text { Continuous electronic } \\
\text { monitoring of medication } \\
\text { adherence }\left(\mathrm{MEMS}^{\mathrm{TM}}\right) \text {, pill } \\
\text { count. }\end{array}$ & $\begin{array}{l}\text { Taking adherence, } \\
\text { dosing adherence }{ }^{a}, \\
\text { timing adherence }{ }^{\mathrm{a}} \text {, total } \\
\text { and LDL-cholesterol. }\end{array}$ & 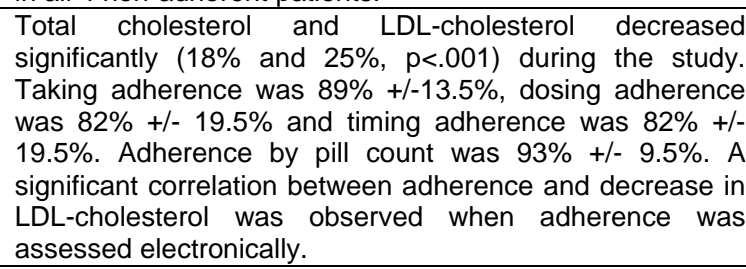 \\
\hline $\begin{array}{l}\text { Arnet et al. }{ }^{10} \text { Design: transversal. } \\
\text { Aim: to correlate patients' statements on their } \\
\text { adherence before hospitalization with their personal } \\
\text { knowledge and convictions about their treatment. } \\
\text { Duration:- } \\
\text { Subjects at inclusion: } 100\end{array}$ & $\begin{array}{l}\text { One structured interview } \\
\text { per patient during } \\
\text { hospitalization on an } \\
\text { internal medicine ward. }\end{array}$ & $\begin{array}{l}\text { Self-reported adherence, } \\
\text { specific knowledge as for } \\
\text { example name of } \\
\text { medications, personal } \\
\text { perception of prescribed } \\
\text { medication. }\end{array}$ & $\begin{array}{l}78 \% \text { subjects reported good adherence, while } 13 \% \\
\text { admitted nonadherence. Knowledge was significantly } \\
\text { better in adherent patients ( } p=.048) \text {. Personal perception } \\
\text { did not differ by adherers and nonadherers. Subjects used } \\
3 \text { main strategies to ensure adherence: visual aids }(69 \%) \text {, } \\
\text { coupling to a ritual }(26 \%) \text {, supervision by a third person } \\
(6 \%) \text {. }\end{array}$ \\
\hline $\begin{array}{l}\text { Stubi et al. }{ }^{17} \text { Design: randomized, open, one-site. } \\
\text { Aim: to assess adherence to oral combined to written } \\
\text { recommendations vs. oral recommendations to live oral } \\
\text { Ty21a typhoid vaccine in travelers regarding dosing, } \\
\text { timing with respect to food intake. } \\
\text { Duration: } 5 \text { days } \\
\text { Intervention: } 55 \\
\text { Control: } 60\end{array}$ & $\begin{array}{l}\text { Continuous electronic } \\
\text { monitoring of medication } \\
\left.\text { adherence (MEMS }{ }^{\mathrm{TM}}\right) \text {, pill } \\
\text { count, self-administered } \\
\text { questionnaire. }\end{array}$ & $\begin{array}{l}\text { Percentage of adherers: } \\
\text { taking all } 3 \text { pills, on } \\
\text { alternate days, at least } \\
\text { one hour before a meal. }\end{array}$ & $\begin{array}{l}\text { No difference in adherence was shown by group. All } \\
\text { subjects took the } 2 \text { capsules but only } 53 \% \text { subjects adhere } \\
\text { to all recommendations according to the electronic } \\
\text { monitors and } 68 \% \text { to the questionnaire }(p=.05) \text {. }\end{array}$ \\
\hline
\end{tabular}




\begin{tabular}{|c|c|c|c|}
\hline Study characteristics & $\begin{array}{l}\text { Measuring methods for } \\
\text { adherence }\end{array}$ & Study outcomes & Results \\
\hline $\begin{array}{l}\text { Burnier et al. }{ }^{12} \text { Design: one-arm, observational, } \\
\text { longitudinal, one-site. } \\
\text { Aim: to evaluate benefits of electronic monitoring of } \\
\text { medication adherence in the management of patients } \\
\text { with resistant hypertension. } \\
\text { Duration: } 4 \text { months } \\
\text { Number of subjects at inclusion: } 41\end{array}$ & $\begin{array}{l}\text { Continuous electronic } \\
\text { monitoring of medication } \\
\text { adherence (each single } \\
\text { antihypertensive drug was } \\
\text { delivered in a MEMSTM } \\
\text { monitor). For the first } 2 \\
\text { months, patient's usual } \\
\text { treatment was provided in } \\
\text { MEMS TM without any } \\
\text { other intervention; for the } \\
\text { next } 2 \text { months, treatment } \\
\text { could be adapted if } \\
\text { necessary. }\end{array}$ & $\begin{array}{l}\text { Dosing adherence, blood } \\
\text { pressure. }\end{array}$ & $\begin{array}{l}\text { Monitoring of adherence alone was associated with an } \\
\text { improvement in BP }(p<.01) \text {. BP was normalized in one- } \\
\text { third of patients. Patients with lowest adherence had higher } \\
\text { diastolic BP }(p=.04) \text {. }\end{array}$ \\
\hline $\begin{array}{l}\text { Bertholet et al. }{ }^{11} \text { Design: retrospective, one-site. } \\
\text { Aim: to evaluate whether the use of electronic } \\
\text { monitoring for medication adherence is a useful } \\
\text { approach to identify compliance problems in } \\
\text { hypertensive patients. } \\
\text { Duration: } 2 \text { months } \\
\text { Number of subjects at inclusion: } 69\end{array}$ & $\begin{array}{l}\text { Continuous electronic } \\
\text { monitoring of medication } \\
\text { adherence (one MEMS } \\
\text { monitor per medication) }\end{array}$ & $\begin{array}{l}\text { Taking adherence, blood } \\
\text { pressure. }\end{array}$ & $\begin{array}{l}\text { Significant decrease in BP (from } 159 / 104+/-23 / 12 \mathrm{mmHg} \\
\text { to } 143 / 92+/-20 / 15, \quad p<.001 \text { ) after inclusion. BP was } \\
\text { normalized in one third of patients. Mean adherence of } \\
\text { patients with normalized BP was } 90.7 \% \text { (range, } 64-100 \% \text { ), } \\
\text { and was similar in the non-normalized patients. }\end{array}$ \\
\hline $\begin{array}{l}\text { Arnet et al. }{ }^{19} \text { Design: open, longitudinal, one-site. } \\
\text { Aim: to evaluate accuracy of electronic adherence } \\
\text { monitoring of an oral vitamin combination. } \\
\text { Duration: } 3 \text { weeks } \\
\text { Subjects at inclusion: } 37\end{array}$ & $\begin{array}{l}\text { Continuous electronic } \\
\text { monitoring of medication } \\
\left.\text { adherence (MEMS }{ }^{\mathrm{TM}}\right) \text {, pill } \\
\text { count, patient interviews. }\end{array}$ & Taking adherence & $\begin{array}{l}\text { Taking adherence was } 102 \% \text {. Pill boxes were opened } \\
>\text { once a day by } 10 \text { patients on a least one monitored day. } \\
\text { In } 7 \text { patients, the number of openings exceeded the } \\
\text { number of capsules provided but only } 2 \text { patients admitted } \\
\text { overconsumption. }\end{array}$ \\
\hline $\begin{array}{l}\text { Wermeille et al. }{ }^{18} \text { Design: longitudinal, one-site. } \\
\text { Aim: to evaluate if poor adherence is a predictor of low } \\
\text { Helicobacter pylori eradication. } \\
\text { Duration: one week } \\
\text { Subjects at inclusion: } 78\end{array}$ & $\begin{array}{l}\text { Continuous electronic } \\
\text { monitoring of medication } \\
\left.\text { adherence (MEMS }{ }^{\mathrm{TM}}\right) \text {. }\end{array}$ & $\begin{array}{l}\text { H. pylori eradication rate, } \\
\text { percentage of subjects } \\
\text { taking more than } 85 \% \text { of } \\
\text { their doses. }\end{array}$ & $\begin{array}{l}\text { H. pylori eradication rate was } 65 \% \text { ( } 95 \% \text { Cl: } 54.8-76.0 \%) \text {. } \\
89 \% \text { of subjects were adherers. On multivariate analysis, } \\
\mathrm{H} \text {. pylori eradication was inversely associated with poor } \\
\text { adherence ( } p=.029) \text {. Poor adherence and bacterial } \\
\text { resistance explained } 40 \% \text { of failures. }\end{array}$ \\
\hline $\begin{array}{l}\text { Schneider et al. }{ }^{15} \text { Design: one-arm, longitudinal, one- } \\
\text { site. } \\
\text { Aim: to characterize use of a nicotine nasal spray } \\
\text { (NNS) in smoking cessation. } \\
\text { Duration: } 18 \text { months } \\
\text { Number of subjects at inclusion: } 92\end{array}$ & $\begin{array}{l}\text { Nasal spray use was } \\
\text { monitored by a microchip } \\
\text { fixed on the spray unit } \\
\text { (microswitch-actuated } \\
\text { metered-dose inhaler } \\
\text { chronolog, MDILog }{ }^{\mathrm{TM}} \text { ). }\end{array}$ & $\begin{array}{l}\text { Number of abstainers at } \\
12 \text { and } 4 \text { months; pattern } \\
\text { of use of NNS. }\end{array}$ & $\begin{array}{l}\text { Success rate was } 17.4 \% \text { at } 12 \text { and } 9.8 \% \text { at } 24 \text { months. } \\
\text { Abstainers use NNS more than failures ( } 12 \text { vs. } 6 \text { puffs/day, } \\
p=.05) \text {, use it less in the morning compared with failures } \\
(26.6 \text { vs. } 32.8 \% \text { of total median daily dose, } p=.03 \text { ) but used } \\
\text { it more in the evening/night ( } 35.3 \text { vs. } 26.7 \% \text { of total median } \\
\text { daily dose, } p=.007) \text {. }\end{array}$ \\
\hline
\end{tabular}




\begin{tabular}{|c|c|c|c|}
\hline Study characteristics & $\begin{array}{l}\text { Measuring methods for } \\
\text { adherence }\end{array}$ & Study outcomes & Results \\
\hline $\begin{array}{l}\text { Landry et al. }{ }^{14} \text { Design: open, longitudinal, } \\
\text { observational. } \\
\text { Aim: to assess adherence to mefloquine malaria } \\
\text { chemoprophylaxis in adult travelers to sub-Saharan } \\
\text { Africa. } \\
\text { Duration: variable } \\
\text { Number of subjects at inclusion: } 81\end{array}$ & $\begin{array}{l}\text { Continuous electronic } \\
\text { monitoring of medication } \\
\left.\text { adherence (MEMS }{ }^{\mathrm{TM}}\right) \\
\text { self-administered } \\
\text { questionnaire on drug } \\
\text { intake }\end{array}$ & $\begin{array}{l}\text { Taking of all the tablets } \\
\text { at the right day. }\end{array}$ & $\begin{array}{l}\text { Only } 26 \text { travelers (32\%) took all the doses at the expected } \\
\text { date. } 19 / 81(24 \%) \text { took them with intervals of }+/-1 \text { day. }\end{array}$ \\
\hline $\begin{array}{l}\text { Santschi et al. }{ }^{20} \text { Design: randomized, cross-over. } \\
\text { Aim: to evaluate acceptability of IDAS II, a new } \\
\text { electronic device for monitoring adherence in } \\
\text { hypertension } \\
\text { Duration: } 2 \times 2 \text { months } \\
\text { Number of subjects at inclusion: } 24\end{array}$ & $\begin{array}{lr}\text { Intelligent } & \text { Drug } \\
\text { Administration } & \text { System } \\
\text { (IDAS II }^{\mathrm{TM}} & \text { electronic } \\
\text { monitor) vs. } & \text { MEMS } \\
\text { monitor as control. }\end{array}$ & $\begin{array}{l}\text { Patients' opinion on both } \\
\text { devices, rates of } \\
\text { adherence, } \\
\text { pressure. }\end{array}$ & $\begin{array}{l}\text { Patients found MEMS } \text { ME }^{\mathrm{TM}} \text { easier to use than IDAS } \\
(\mathrm{p}<.001) \text { but appreciated IDAS } \\
\text { MEMS blister packs better than } \\
\text { was } 99 \% \text { and comparable }(p<.01) \text {. Median taking adherence } \\
\text { in blood pressure between groups. }\end{array}$ \\
\hline $\begin{array}{l}\text { Figueiredo et al. }{ }^{22} \text { Design: retrospective, one site. } \\
\text { Aim: to describe systolic blood pressure (SBP) and } \\
\text { model it during an adherence-enhancing intervention } \\
\text { program in patients resistant to their treatment. } \\
\text { Duration: variable } \\
\text { Subjects: } 89\end{array}$ & $\begin{array}{l}\begin{array}{l}\text { Continuous } \\
\text { monitoring of }\end{array} \\
\begin{array}{r}\text { electronic } \\
\text { adhedication } \\
\text { (MEMSTM), }\end{array} \\
\text { combined to repeated } \\
\text { interviews with subjects. } \\
\text { Composite adherence } \\
\text { score between electronic } \\
\text { monitoring, pill count and } \\
\text { validated pocket-doses. }\end{array}$ & $\begin{array}{l}\text { Quality of execution }{ }^{\mathrm{a}} \text {, } \\
\text { blood pressure. }\end{array}$ & $\begin{array}{l}\text { Quality of execution was high and stable over time. The } \\
\text { average decrease in SBP from baseline was } 15 \mathrm{mmHg} \text {. } \\
\text { SBP decreased as quality of execution increases with a } \\
\text { maximum around } 85 \% \text { adherence. }\end{array}$ \\
\hline
\end{tabular}


Schneider et al. ${ }^{23}$ Design : randomized, controlled, open, one-site Aim: to evaluate the benefit of online telemonitoring of medication adherence in epilepsy.

Duration: 8 month

Intervention: 12

Control: 14

Santschi et al. ${ }^{9}$ Design: cluster randomized, controlled, and multisites.

Aim: to examine whether monitoring medication adherence with an electronic system improves BP control in uncontrolled patients followed by GPs.

Duration : 12 months

Intervention : 34

Control : 34

Krummenacher et al. ${ }^{8}$ Design: pilot, quasi-experimental, two-sites. Aim: to evaluate the feasibility of an interdisciplinary and multifactorial adherence program in HIV patients starting a first or a second antiretroviral therapy line.

Duration: 6 month

Intervention: 21

Control: 11
Intervention

Electronic monitors of medication adherence (MEMS ${ }^{\mathrm{TM}}$ ) connected to a personal modem (HomeLink ${ }^{\mathrm{TM}}$ ) installed on the subject's telephone line vs. electronic monitors only in controlled subjects. Pharmacist called patient at home in case of drug omission.

Electronic monitoring of medication adherence $\left(\mathrm{MEMS}^{\mathrm{TM}}\right)$, plus non-structured repeated interviews at the pharmacy in the intervention group vs. electronic monitors only in control group.

Continuous electronic monitoring of medication adherence (MEMS $\left.{ }^{\mathrm{TM}}\right)$, combined to repeated motivational interviewing in intervention vs. blinded medication adherence electronic monitoring in control group.

Composite adherence score between electronic monitoring, pill count and validated pocket-doses.
Study outcomes

groups. There was a trend towards less epileptic events in the intervention vs. $(p=.07)$.

\section{Normalized \\ $(<140 / 90 \mathrm{mmHg})$}

BP

Quality of execution and persistence.

\section{The study 051$)$.}

was feasible in one site but not in the other one. Quality of execution was high in both groups $(97 \%$ vs. $95 \%)$ but decreased statistically more over time in group $(p<.0001)$.

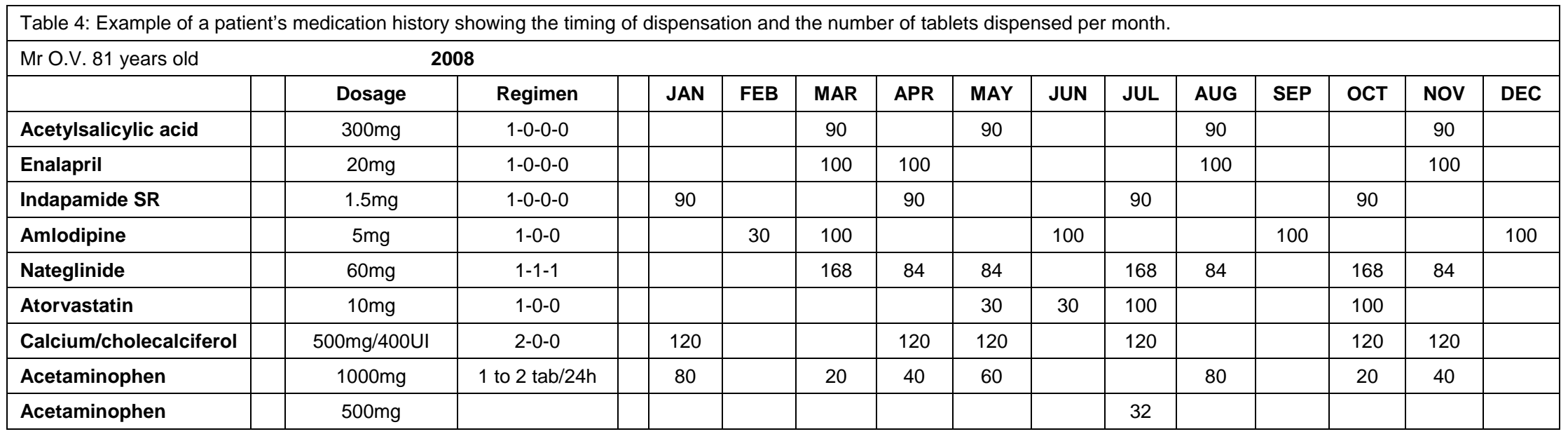

